\title{
Bacillaemia in leprosy and effect of multidrug therapy
}

\author{
G CHATTERJEE, * S KAUR, $\ddagger$ V K SHARMA, * \\ C VAISHNAVI $\dagger \&$ N K GANGULY $\dagger$ \\ Departments of Dermatology* and Experimental Medicine, $\dagger$ Post- \\ graduate Institute of Medical Education and Research, Chandigarh- \\ 160012 , India
}

Accepted for publication 23 March 1989

\begin{abstract}
Summary Twenty-five patients of bacilliferous leprosy (17 LL, 8 BL) were studied by the modified haemolysis method for occurrence of bacillaemia and its clearance after two multidrug therapy regimens. Acid-fast bacilli were found in $76 \%$ of all patients and in $88.2 \% \mathrm{LL}$ and $50 \%$ BL patients. Bacillaemia occurred with significantly reduced frequency in patients with type II reaction. Acid-fast bacilli were demonstrable in peripheral blood after 1 month in one patient on MDT of an Indian Working Group and 3 lepromatous patients on WHO multidrug therapy. However, bacillaemia could not be demonstrated in any patients after 2 and 3 months of treatment with both regimens.
\end{abstract}

\section{Introduction}

Bacillaemia, the finding of lepra bacilli in peripheral circulation, has been a topic of investigation since the turn of the century. ${ }^{1}$ Initially bacillaemia was demonstrated in lepromatous leprosy, ${ }^{2,3}$ recently, it has been documented even in tuberculoid leprosy. ${ }^{4,5}$ The bacillaemia has been attributed to multisystem involvement in lepromatous leprosy. ${ }^{4}$ It was planned to study the occurrence of bacillaemia in lepromatous patients and assess the efficacy of multidrug therapy regimens in the clearance of bacillaemia.

\section{Materials and methods}

Twenty-five untreated patients having bacilliferous leprosy (LL/BL) formed the study group. There were 22 males and 3 females, with an age range of 16-58 years (mean 37.5). Ridley-Jopling classification was followed. ${ }^{6} \mathrm{~A}$ haemogram, urinalysis, chest skiagram, hepatic and renal function tests were carried out before starting therapy in all cases.

$\ddagger$ Correspondence

0305-7518/89/060197+05\$01.00 C British Leprosy Relief Association 


\section{BACILLAEMIA STUDIES}

Three samples of blood at 12-hr intervals were collected before starting the treatment. Repeat samples were taken at 1,2 and 3 months in the first 10 patients and at 2 week intervals 1,2 and 3 months after treatment in the remaining 15 patients. A total of 2 blood samples were collected at 12-hr intervals for the follow-up studies for bacillaemia, and a modified haemolysis method ${ }^{7}$ was used for study. Briefly, $5 \mathrm{ml}$ of blood was drawn from the antecubital vein and transferred to a heparanized vial $(10 \mathrm{iu} / \mathrm{ml})$. One millilitre of blood from the above was transferred to a half test-tube and the cells were disintegrated by ultrasonic vibrations $(800 \mathrm{KHz})$ for $30 \mathrm{~s}$. One millilitre of sterile distilled water was added and the sample was sonicated again for $30 \mathrm{~s}$. This step was repeated to get a final volume of $4 \mathrm{ml}$. The same procedure was repeated with the remaining $4 \mathrm{ml}$ of blood to make a final volume of $20 \mathrm{ml}$. It was centrifuged at $10,000 \mathrm{rpm}$ for $30 \mathrm{~min}$ at $10^{\circ} \mathrm{C}$ in a propylene centrifuge tube. The supernatant was removed, and the deposit was washed and centrifuged again with $20 \mathrm{ml}$ of sterile distilled water at the same speed for $20 \mathrm{~min}$. The deposit was suspended in $1 \mathrm{ml}$ of distilled water and a bacillary count done using the pinhead method. ${ }^{8}$ The smears were made for ZiehlNeelsen staining and studied under an oil-immersion microscope.

\section{TREATMENT AND FOLLOW UP}

Group I. The 10 consecutive patients ( $7 \mathrm{LL}, 3 \mathrm{BL}$ ) were treated with WHO multibacillary regimen consisting of rifampicin $600 \mathrm{mg}$ and clofazimine $300 \mathrm{mg}$ once a month given under supervision, and dapsone $100 \mathrm{mg}$ daily and clofazimine $100 \mathrm{mg}$ on alternate days, selfadministered. ${ }^{9}$

Group II. The 15 consecutive patients (10 LL, $5 \mathrm{BL})$ were treated with the India Working Group's multibacillary MDT consisting of intensive therapy with rifampicin $600 \mathrm{mg}$, clofazimine and dapsone $100 \mathrm{mg}$ daily for 15 days and continued on the maintenance phase like the WHO multibacillary regimen. ${ }^{10}$ The bacteriological and morphological indices (BI and $\mathrm{MI}$ ) were repeated at 1,2 and 3 months af ter therapy.

\section{Results}

The mean duration of the disease in 25 patients was 3.4 years. The average bacteriological (BI) and morphological (MI) indices were $3 \cdot 9+/ 3 \cdot 28 \%$ and $3 \cdot 3 / 1 \cdot 07 \%$ in LL and BL patients respectively. Seventeen patients of lepromatous leprosy (LL) included 12 polar lepromatous (LLp), 4 subpolar lepromatous leprosy (LLs), and 1 with histoid leprosy. Five LL patients had Type II reaction. The patients in group I and II were comparable in age, sex, duration, type of disease and average BI and MI. Bacillaemia was found in $19(76 \%)$ out of 25 patients, $15(88.2 \%)$ were LL out of 17 taken up and $4(50.0 \%)$ were BL out of 8 patients taken up (Table 1). No statistically significant difference

Table 1. Bacillaemia in multibacillary leprosy

\begin{tabular}{lcc}
\hline Type of leprosy & No. studied & No. $(\%)$ showing bacillaemia \\
\hline LL & 17 & $15(88 \cdot 2)$ \\
BL & 8 & $4(50 \cdot 0)$ \\
\hline Total & 25 & $19(76 \cdot 0)$ \\
\hline \multicolumn{3}{c}{$\chi^{2}=2 \cdot 7 ; p>0.05}$.
\end{tabular}




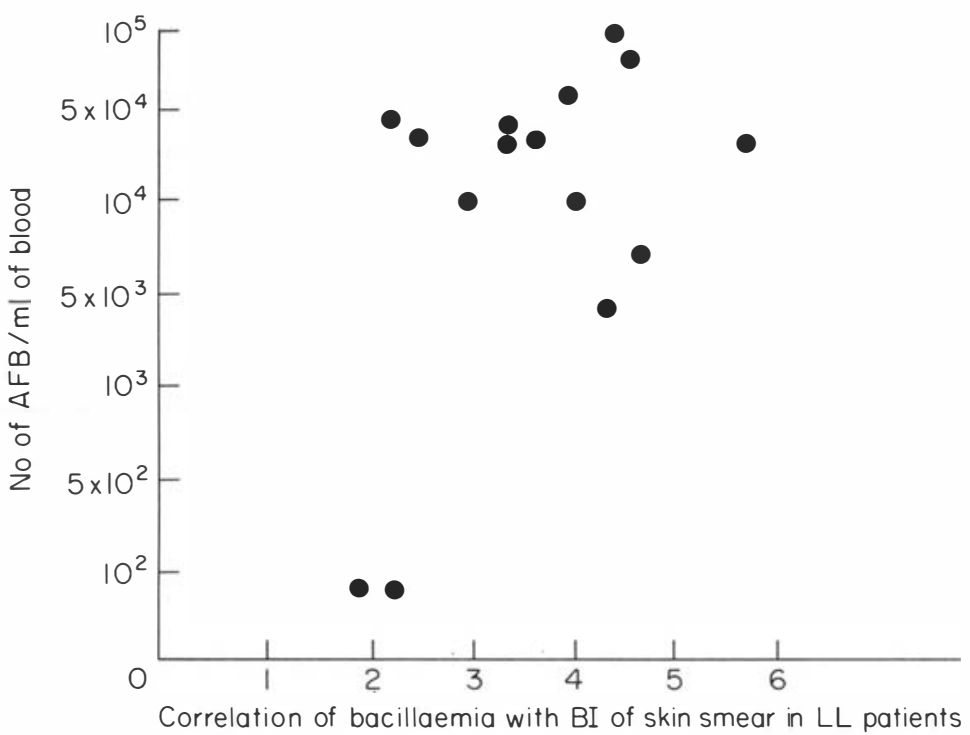

Figure 1.

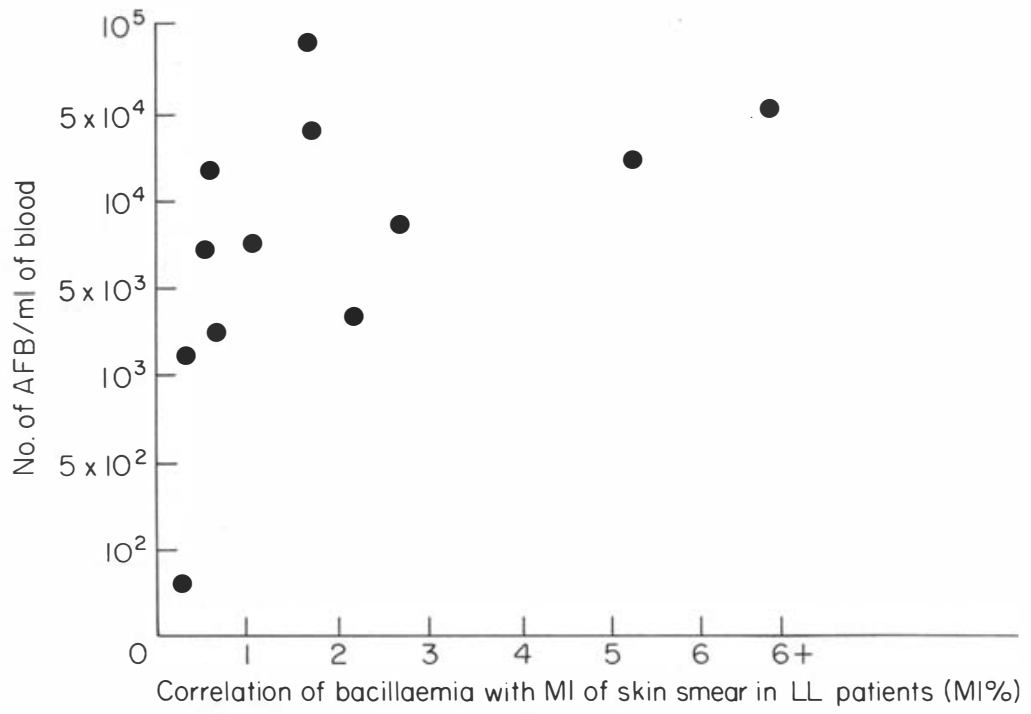

Figure 2.

was found in the frequency of bacillaemia in lepromatous and borderline lepromatous leprosy $\left(\chi^{2}=2 \cdot 24 ; p>0 \cdot 05\right)$. However, there was a statistically significant difference in the frequency of bacillaemia in patients with and without Type II reaction $\left(\chi^{2}=4.48 ; p<0.05\right)$, as only 3 out of 5 patients with Type II reaction showed bacillaemia. The correlation between bacillaemia and bacteriological index was good (Figure 1) and no correlation was demonstrated between bacillaemia and morphological index in slit-skin smears (Figure 2). 
Table 2. Bacillaemia clearance af ter multidrug therapy

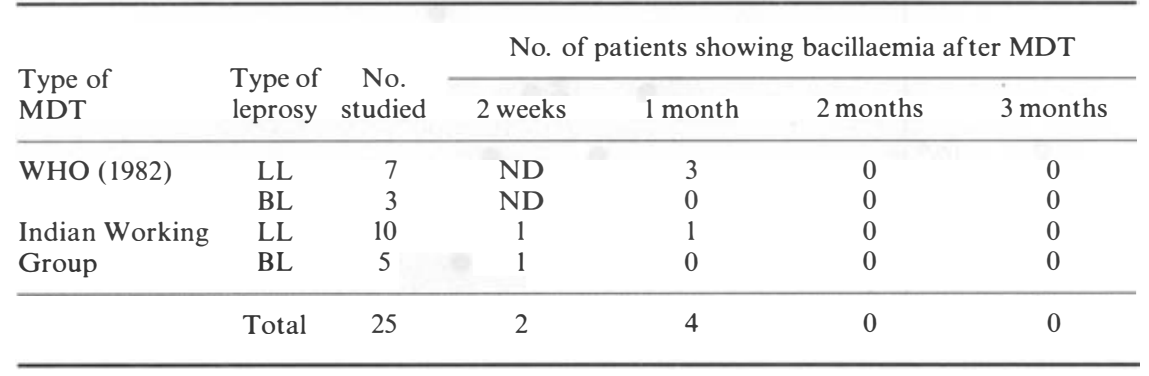

ND, not done.

The bacilli could not be demonstrated in peripheral blood 2 and 3 months af ter therapy in all the patients. However, bacilli were still demonstrable after 1 month in 3 out of 7 LL patients on WHOMDT regimen (Group I) and in 1 out of $10 \mathrm{LL}$ patients on the Indian Working Group regimen (Group II) (Table 2). The clearance of bacillaemia after 1 month of each of the two MDT regimens was not different $\left(\chi^{2}=2 \cdot 24, p>0 \cdot 05\right)$ though it seems that the Indian Working Group regimen resulted in earlier clearance. There was no significant reduction in $\mathrm{BI}$, however MI was reduced to zero after 3 months of MDT.

\section{Discussion}

Bacillaemia occurs in $67-100 \%$ patients of bacilliferous leprosy. ${ }^{2-4,11}$ The frequency of demonstration of bacillaemia has progressively increased with the modification of methodology., $4,7,12,13$ Circulating bacilli were found in $92-100 \%$ patients with lepromatous leprosy (LL) ${ }^{4,11}$ compared to our finding of $88.2 \%$. However, in borderline lepromatous leprosy (BL) bacillaemia occurs less frequently ${ }^{4}$ but there is apparently no direct correlation between frequency of bacillaemia and the bacteriological and morphological indices. ${ }^{3,4}$ There was apparently good correlation between BI of slit-skin smear and bacillaemia in our patients. Sankara Manja et al. ${ }^{13}$ also reported similar results.

Bacillaemia occurred with lower f requency in LL patients with Type II reaction compared to LL patients without reaction and the difference was statistically significant $\left(\chi^{2}=4.48 ; p<0 \cdot 05\right)$. A similar finding has been reported earlier. ${ }^{2,14,15}$ It may be due to stimulation of cell-mediated immunity in Type II reaction resulting in the increased clearance of bacilli. ${ }^{16}$

Drutz et al. ${ }^{2}$ reported gradual clearance of bacillaemia over a 4-month period after dapsone monotherapy. The extracellular bacilli cleared first followed by intracellular bacilli. Subsequently, Ramu et al. ${ }^{17,18}$ assessed bacteraemia in 36 LL patients at weekly intervals for 4 weeks after putting patients on 4 drug regimens, namely dapsone alone, dapsone and clofazimine, dapsone and isoniazide, and dapsone and rif ampicin. They observed that bacillaemia disappeared after one week in the dapsone and rifampicin regimen, while it took 3 weeks with the other regimens. Bacillaemia cleared in all patients by 2 months with different multibacillary regimens in our study. The 15 days intensive multibacillary therapy did not show significant advantage in clearance of bacillaemia. The exact pathogenesis of clearance of bacilli from peripheral circulation in the presence of a heavy bacterial load in skin is not known. Probably the administration of drugs results in immediate bacteriostasis and thereby prevents the further multiplication and overspill from involved vasculature into the circulation. The immunostimulatory effect of antileprotics has been suggested as another possible factor. ${ }^{17,19}$ 


\section{References}

1 Lowe J. Bacillaemia in leprosy. Ind Med Gaz, 1933; 68: 503-6.

2 Drutz DJ, Chen TSN, Lu WH. The continuous bacterimia of lepromatous leprosy. New Engl J Med, 1972; 287: 159-64.

3 Padma MN, Desikan KV. Bacillaemia in leprosy. Ind J Med Res, 1975; 63: 888-92.

4 Raval, Saibhaktiban N, Sen Gupta U, Ramu G, Prabhune PV, Desikan KV. A study of continuous bacillaemia in borderline and lepromatous leprosy. Lepr India, 1982; 54: 623-33.

5 Jayapal V, Bhatia VN. Bacillaemia in smear negative leprosy. Ind J Lepr, 1986; 58: 61.

6 Ridley DS, Jopling WH. A classification for research purposes. Lepr Rev, 1962; 33: 119-128.

7 Sen Gupta U, Ramu G, Desikan KV. Further modification of the haemolysis method in determining bacteremia in leprosy patients. Lepr India, 1983; 55: 670-4.

8 Hanks JH, Chatter jee BR, Lechet MF. A guide to counting of Mycobacterium on clinical and experimental material. Int J Lepr, 1964; 32: 156-9.

y World Health Organisation Study Group. Chemotherapy of leprosy for Control Programmes. WHO Tech Rep Ser, 1982 No. 675.

${ }_{10}$ Working Group Government of India. National Leprosy Eradication Programme. 1982.

11 Veliath AJ, Bedi BMS, Balasubramanyam M. Macrophage culture from untreated leprosy cases. Le pr India, 1980; 52: 203-8.

12 Sreevastva, Sengupta U, Ramu G, Desikan KV. Evaluation of bacteremia in leprosy patients. Le pr India, 1978; 50: 381.

13 Shankara Manja K, Bedi BMS, Kasturi G, Kirchheimer WF, Balasubramanayam M. Demonstration of Mycobacterium leprae and its viability in peripheral blood of leprosy patients. Lepr Rev, 1972; 43: 181-4.

14 Padma MN, Premanathan M, Desikan KV. Bacillaemia in reactive states in leprosy. Lepr India, 1976; 48: 413-18.

15 Zawar PB, Holla VV, Patil S M, Zawar MP, Chewhan RN. Bacillaemia in lepra reaction. Its correlation with liver pathology. Lepr India, 1983; 55: 570-5.

16 Modlin RL, Bakke AC, Vaccaro SA, Horwitz DA, Taylor CR, Rea TH. Tissue and blood T-lymphocytes sub-population in erythema nodosum leprosum. Arch Dermatol, 1985; 121: 216-19.

17 Ramu G, Sreevastva, Sen Gupta U, Desikan KV. Evaluation of multiple regimen in leprosy. Lepr India, 1980; 53: 190.

18 Ramu G, Sreevastva. Evaluation of drug regimens in lepromatous leprosy II. Lepr India, 1983; 55: 200-8.

19 Anderson R. Immunopharmacology of antileprosy agents. Lepr Rev, 1983; 54: 139-44. 